\title{
Anders Sjöborg and Hans-Georg Ziebert, Religion, Education and Human Rights: Theoretical and Empirical Perspectives, Springer International Publishing: Cham, 2017; 212 pp.: ISBN: 9783319540696
}

Reviewed by Anja PogačNIK ${ }^{1}$

This edited volume is a collection of contributions that loosely revolve around the fields of human rights, education, and religion. It grew out of an international workshop on those topics, held in Uppsala, Sweden, in March 2014, at which the contributors explored the relations between religion, human rights, and education to identify relevant areas for future research and develop meaningful research questions' on the topic ( $p$. 2). While the contributing scholars come from a range of different fields and disciplines (including law, theology, religious studies, among others), what connects

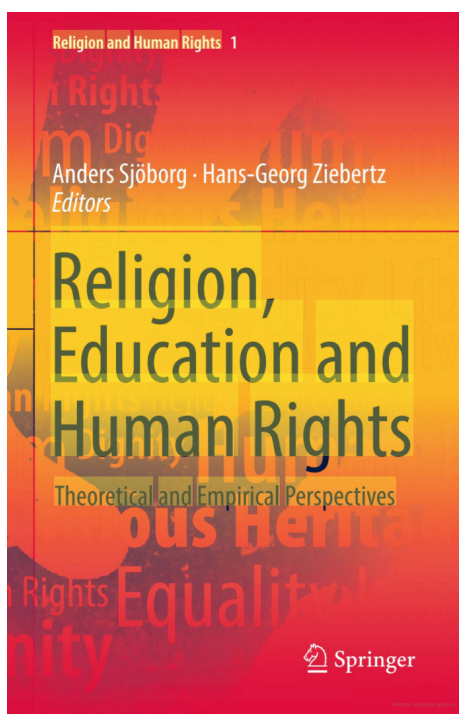
them is a focus on the countries around the Baltic Sea region - Sweden, Norway, Finland, Estonia, Belorussia, Poland, and Germany are all represented in this volume. A range of theoretical and empirical approaches is also represented in the book, with a few chapters employing statistical analysis, some focusing on discourse analysis, while others engaging with law, media, or common educational practices in various ways.

As this is a collection that stems out of a loosely-defined workshop, it is plagued by the problems many such volumes have - namely, a lack of clear focus in its content, wide swings in the quality of contributing chapters, and the absence of an overall aim. Let me tackle these in turn.

The coherence and quality of an edited volume depend (to a large extent) on its editors. While the individual contributors perform the bulk of the work in creating the content of the chapters, it is the responsibility of the editors to provide a clear vision for the book, guide the scholars towards producing an

1 Faculty for Social Sciences, University of Ljubljana, Slovenia; anja.pogacnik@fdv.uni-lj.si. 
adequate contribution to the whole, and then summarise the volume's vision, contributions, and aims in a coherent way that frames the chapters within an overarching narrative. Unfortunately, the editors of this volume - Anders Sjöborg and Hans-Georg Ziebertz - have not been very successful in providing such vision, guidance, or framing of this volume. In their introductory chapter to the volume, they present a rather scant scaffolding for the book's content with nods to various declarations of human rights, clichés and personally motivated statements, ${ }^{2}$ and by spending the bulk of the chapter summarising the subsequent chapters of the volume, without ever providing a framework for how they fit together. The general aim of the book and its focus are left undefined for the reader - and one would guess for the writers as well. Engagement with the wider literature on the topic and its adjacent fields is also incredibly limited, ${ }^{3}$ although the fact that there is value in setting the stage for the subsequent discussions through an exploration of the state of the field and situating the volume in the larger corpora of religion, education, and human rights should go without saying.

Given that the editors' guidance as to the focus of the book was presumably less than ideal, it is no surprise that the contributing authors interpreted the key concepts of religion, education, and human rights in a range of different ways, sometimes with only tentative connections to one or two of the keywords ${ }^{4}$ in the book's title and often without a clear focus for their chapters. Most of the chapters meander through loosely connected topics in the hope of it all adding up to an argument, without much clarity, vision, or purpose. Many chapters offer only limited critical engagement with the presented content, and the vast majority of contributions are incredibly short; whether that is due to the directive by the book's editors remains unclear. The chapters are typically cut off after about a dozen pages of text, apparently before the authors had time to dive into the depths of their topics after

2 '[R] eligious education has to develop programmes that do not cover the ambivalence [of religion being used to either affirm or deny human rights] but develop concepts from the inner heart of the religion, which can work as a religious source for modern liberties. A key concept is the dignity of every person, given by the likeness of God, who determined for people to have freedom and to live in charity with his/her neighbours' (p. 8, emphasis added).

3 The literature review from Hans-Georg Ziebertz's How Young Muslims and Christians Structure Human Rights: An Empirical Study in Germany (Chapter 9) would have found a better place in the introductory Chapter 1 .

4 For example, Chapter 12 (Good Practice in Human Rights Education in Schools by Paula Gerber) mentions religion in one single sentence on its twenty-four pages, while the contributions of the editors (Chapter 9: How Young Muslims and Christians Structure Human Rights: An Empirical Study in Germany by Hans-Georg Ziebertz, and Chapter 10: The Influence of the Socio-Cultural Environment and Personality on Attitudes Toward Human Rights: An Empirical Study in Reference to Human Rights Education by Hans-Georg Ziebertz, Alexander Unser, Susanne Döhnert, and Anders Sjöborg) barely touch the topic of education. 
swimming in the shallow waters of vagueness and a lack of clarity as to what exactly they would like to say.

A few contributions, however, should be singled out due to their clear focus, well-defined research questions, and well-argued content. Katarzyna Zielińska and Marcin K. Zwierżdżyński in their chapter Sacred or Profane? Human Rights in Religion Education in Poland (Chapter 2) give a comprehensive introduction to the Polish religious context and its organisation of (confessional) religious education (RE) in schools, before presenting a well-structured and indepth analysis of the discourse Catholic, Orthodox, and Pentecostal RE textbooks employ when discussing the topic of human rights. Similarly, the chapter by Olga Schihalejev and Ringo Ringvee on the Silent Religious Minorities in Schools in Estonia (Chapter 5) compares three different modes of religious education - no RE, confessional RE, and non-confessional RE - and their relation to the level of respect for the right to freedom of religion and belief expressed by pupils. In this well-supported, quantitative chapter, they argue that RE (both confessional and non-confessional) is better for the promotion of human rights than the absence of RE in schools. Dan-Erik Andersson's chapter Teaching the History of Human Rights (Chapter 7) looks at how the history of human rights and its relationship with religion is presented in school textbooks. By discussing three examples of complexity in the above-mentioned relationship, he argues against a simplistic narrative of religion's role in the history of human rights, presenting an engaging, interesting, and strongly argued chapter. Lastly, we could also mention Kavot Zillén's chapter Conscientious Objections in Clinical Healthcare Education as a Manifestation of Religion (Chapter 11) as an example of a focused and clearly argued text, where she explores various dimensions of conscientious objection in healthcare education, though her contribution engages with the topic of education only to the extent that her general discussion of freedom of religion and conscientious objection in medical service is situated within the educational setting.

The rest of the chapters in this book mostly leave the reader with an impression that the ideas behind them were good but rather poorly executed. While singling out examples of particularly disappointing chapters would not serve any purpose, such oscillation between chapters of higher and lower quality is, unfortunately, an all too common feature of volumes that emerge out of conferences, panels, or workshops. The lack of a clear overall focus by the book's editors certainly could not have had a beneficial influence on the contributions made by the other authors.

Overall, this is a rather disappointing volume, which does not live up to the promise of its title - Religion, Education and Human Rights. While some 
chapters will provide a worthwhile read to those engaged in similar research topics, the book as a whole would find readers only in those upon whom it was imposed as prescribed reading. 